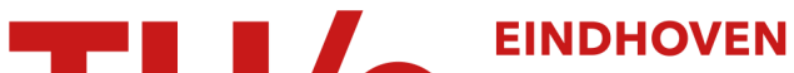 \\ UNIVERSITY OF \\ TECHNOLOGY
}

\section{Macrocyclization of enzyme-based supramolecular polymers}

\section{Citation for published version (APA):}

Bastings, M. M. C., Greef, de, T. F. A., Dongen, van, J. L. J., Merkx, M., \& Meijer, E. W. (2010). Macrocyclization of enzyme-based supramolecular polymers. Chemical Science, 1(1), 79-88. https://doi.org/10.1039/c0sc00108b

DOI:

10.1039/c0sc00108b

Document status and date:

Published: 01/01/2010

\section{Document Version:}

Publisher's PDF, also known as Version of Record (includes final page, issue and volume numbers)

\section{Please check the document version of this publication:}

- A submitted manuscript is the version of the article upon submission and before peer-review. There can be important differences between the submitted version and the official published version of record. People interested in the research are advised to contact the author for the final version of the publication, or visit the $\mathrm{DOI}$ to the publisher's website.

- The final author version and the galley proof are versions of the publication after peer review.

- The final published version features the final layout of the paper including the volume, issue and page numbers.

Link to publication

\section{General rights}

Copyright and moral rights for the publications made accessible in the public portal are retained by the authors and/or other copyright owners and it is a condition of accessing publications that users recognise and abide by the legal requirements associated with these rights.

- Users may download and print one copy of any publication from the public portal for the purpose of private study or research.

- You may not further distribute the material or use it for any profit-making activity or commercial gain

- You may freely distribute the URL identifying the publication in the public portal.

If the publication is distributed under the terms of Article 25fa of the Dutch Copyright Act, indicated by the "Taverne" license above, please follow below link for the End User Agreement:

www.tue.nl/taverne

Take down policy

If you believe that this document breaches copyright please contact us at:

openaccess@tue.nl

providing details and we will investigate your claim. 


\title{
Macrocyclization of enzyme-based supramolecular polymers $\dagger$
}

\author{
Maartje M. C. Bastings, ${ }^{a b}$ Tom F. A. de Greef, ${ }^{a c}$ Joost L. J. van Dongen, ${ }^{c}$ Maarten Merkx ${ }^{b}$ \\ and E. W. Meijer $* a b c$
}

\author{
Received 5th January 2010, Accepted 1st February 2010 \\ First published as an Advance Article on the web 18th March 2010 \\ DOI: $10.1039 / \mathrm{c0sc00108b}$
}

\begin{abstract}
AB type monomers for supramolecular polymers have been developed based on the strong and reversible noncovalent interaction between ribonuclease S-peptide (A) and S-protein (B), resulting in an active enzyme complex as the linking unit. Two AB-type protein constructs are synthesized differing in the length of the flexible oligo(ethylene glycol) spacer separating the two end groups. Using an experimental setup where size exclusion chromatography is directly coupled to Q-TOF mass spectrometry, we have analyzed the self-assembled architectures as a function of concentration. The theory of macrocyclization under thermodynamic control is used to quantitatively analyze the experimental data. Using this theory, we show that AB-type monomers linked by flexible linkers grow reversibly via ring-chain competition. Inherently the formation of linear polymeric assemblies is beyond the capability of these types of building blocks due to concentration limits of proteins. The results therefore contribute to the general understanding of supramolecular polymerization with biological building blocks and demonstrate design requirements for monomers if linear polymerization is desired.
\end{abstract}

\section{Introduction}

Supramolecular polymer chemistry has emerged from the combination of supramolecular chemistry and polymer science, and focuses on the development of individual monomeric units, held together by strong, directional and reversible noncovalent interactions. ${ }^{1}$ The reversibility and temperature dependence of noncovalent interactions allows the development of novel polymeric materials that combine excellent mechanical properties and good processability at low temperatures. ${ }^{2}$ Based on the current understanding ${ }^{1 p}$ there are three main growth mechanisms for supramolecular polymerizations: isodesmic ${ }^{3}$ cooperative $^{4}$ and ring-chain competition, ${ }^{5}$ in which the linear polymers are in equilibrium with their cyclic counterparts. In the last two cases there exists a critical concentration above which high-molecular weight supramolecular polymers are formed. In Nature, many examples of supramolecular architectures assembled from monomeric protein building blocks exist, which follow identical growth mechanisms as synthetic supramolecular polymers. Wellknown examples hereof include the cooperative growth of actin monomers into filaments, ${ }^{6}$ the isodesmic assembly of FtsZ proteins into the Z-ring during cell-division ${ }^{7}$ and serpin polymerization, ${ }^{8}$ in which cyclic intermediates play a prominent role.

anstitute for Complex Molecular Systems, Eindhoven University of Technology, P.O. Box 513, 5600 MB Eindhoven, The Netherlands. E-mail: e.w.meijer@tue.nl

${ }^{b}$ Laboratory of Chemical Biology, Eindhoven University of Technology, P.O. Box 513, 5600 MB Eindhoven, The Netherlands

${ }^{c}$ Laboratory of Macromolecular and Organic Chemistry, Eindhoven University of Technology, P.O. Box 513, 5600 MB Eindhoven, The Netherlands

$\dagger$ Electronic supplementary information (ESI) available: Detailed experimental procedures. Analytical characterization data of all compounds. DLS. Extended simulations on ring-chain equilibria. Detailed SEC flow-speed analysis. See DOI: $10.1039 / \mathrm{c} 0 \mathrm{sc} 00108 \mathrm{~b}$
For biomedical applications such as drug delivery and tissue engineering, biomolecular complexes have great potential as structural units in supramolecular polymers because of their biocompatibility, biodegradability and inherent stability in water. Furthermore, because the noncovalent interaction between the associating end groups can be tuned using methods developed in protein engineering, the macroscopic properties of the resulting supramolecular materials can be tailored for specific applications.

The combination of biological macromolecules with synthetic components to yield semi-synthetic or hybrid molecules, offers the possibility to combine the strengths of biology and chemical synthesis. ${ }^{9}$ Biological architectures are constructed with high fidelity but the variety of building blocks is limited. Synthetic chemistry on the other hand provides an infinite variation in topology but is less efficient in error-free synthesis. Merging both fields yields a challenging approach to assemble and study semisynthetic protein architectures. Linking protein and substrate through a flexible linker enables the synthesis of interesting supramolecular building blocks and provides opportunity in the rapidly emerging field of supramolecular protein engineering. Recently, several groups have reported on synthetic supramolecular polymers based on protein-ligand interactions. ${ }^{1 j, 10,11}$ For example, Hayashi and co-workers ${ }^{1 j, 10}$ reported the formation of linear supramolecular polymers based on heme proteins to which an external cofactor moiety was appended via a flexible spacer. This one-dimensional concept was further expanded to two dimensions by mixing in a heme-triad to enable network formation. Recently Wagner et al. ${ }^{11}$ presented an in-depth study on the assembly of discrete protein nano-rings by combining a dimeric protein construct with a flexible spacer and a divalent synthetic ligand.

These two examples demonstrate that both linear as well as discrete cyclic assemblies can be obtained using flexible spacers. 
Indeed, it is well known that the use of flexible linkers inherently brings along the formation of cycles. In the early 1930s Kuhn ${ }^{12}$ introduced the concept of effective concentration $\left(C_{\text {eff }}\right)$ to provide a relation between the mean squared end-to-end length of a linker and the cyclization probability of the end groups when the two ends of the linker are an infinitesimal distance apart. The effective concentration can be thought of as the local concentration of one chain end in the vicinity of the other chain end when these two ends are connected by a linker. As such, the $C_{\text {eff }}$ theoretically quantifies the advantage for an intra- $v s$. an intermolecular interaction. Because the $C_{\text {eff }}$ depends on the length and conformational flexibility of the linker, changes in these values will have a pronounced effect on the supramolecular polymerization of monomeric building blocks and should therefore be taken into consideration in the design process. Besides the effective concentration, other factors such as the presence of linker strain or specific noncovalent interactions within oligomeric assemblies can also play a crucial role in the supramolecular polymerization process as will be shown in this paper.

The objective of this work is to quantitatively analyze and study the mechanism of the supramolecular polymerization of biological building blocks in which the reversibly associating A and $\mathrm{B}$ end groups are separated by a flexible spacer. To this end, an $\mathrm{AB}$ monomer was developed based on the strong,

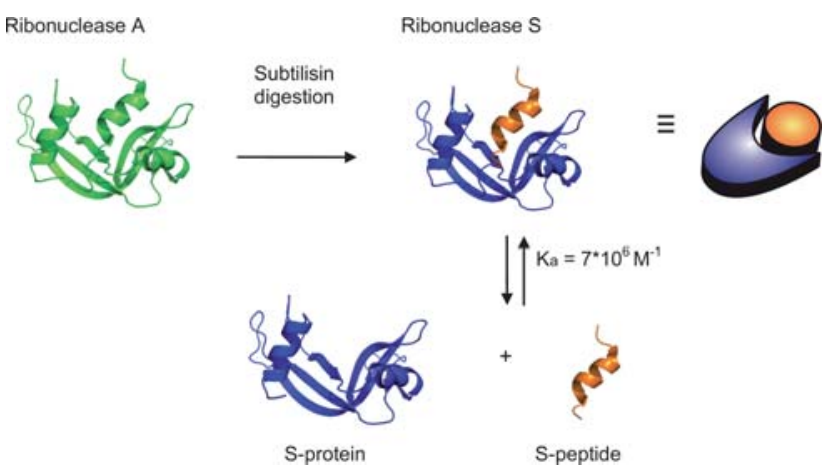

Scheme 1 The formation of ribonuclease S upon cleavage of ribonuclease A by the protease subtilisin. Ribonuclease $\mathrm{S}$ can be separated into the S-peptide and S-protein that form a tightly bound supramolecular complex. noncovalent interaction between the ribonuclease (RNase) S-protein and S-peptide (Scheme 1, $K_{\mathrm{a}} \sim 7 \times 10^{6} \mathrm{M}^{-1}$ in NaOAc at $\left.25{ }^{\circ} \mathrm{C}\right),{ }^{13}$ thereby constructing supramolecular architectures entirely consisting of enzymatically active proteins as linking units. This RNase $\mathrm{S}$ system has previously been successfully used in the noncovalent synthesis of protein dendrimers by our group. ${ }^{14}$ Both $\mathrm{S}$-protein and $\mathrm{S}$-peptide were connected via a flexible oligo(ethylene glycol) (EG) linker. EG linkers are commonly used to construct multivalent ligands and are known to be resistant to nonspecific protein adsorption. ${ }^{15}$ This minimizes the influence of the protein fragments on the flexibility and thus the $C_{\text {eff }}$ of the linker. Upon successive addition of monomers to the growing chain, the $\mathrm{AB}$ building block can undergo cyclic as well as linear polymerization, the distribution of which is determined by the effective molarity of each oligomer and the overall monomer concentration. The influence of the length of the EG linker on the supramolecular polymerization will be experimentally demonstrated using concentration dependent size exclusion chromatography and the results obtained will be quantitatively analyzed using the theory of macrocyclization under thermodynamic control. Finally, a comparison is made between the experimentally determined product compositions and a reversible isodesmic polymerization model in which no cyclization occurs.

\section{Results and discussion}

\section{AB monomer synthesis and characterization}

$\mathrm{AB}$ monomers were synthesized using aniline catalyzed oxime chemistry ${ }^{16}$ which requires the introduction of either an aldehyde/ketone function or aminooxy functionality on the peptide and protein. The S-protein is formed after subtilisin digestion of RNase A (Scheme 1) and consists of residues 21-124. Because serine is the natural $\mathrm{N}$-terminal residue on the RNase $\mathrm{S}$ protein an aldehyde can be easily obtained via oxidation using $\mathrm{NaIO}_{4}{ }^{17}$ Heterogeneous digestion of RNase A by subtilisin yields a minor cleavage product that corresponds to residues $22-124 ;{ }^{18}$ however, the N-terminal residue here is again a serine. Since no difference in affinity for the S-peptide has been described, and both products can be oxidized and used for oxime ligation, no separation between the two forms was necessary. The aldehyde function on the S-peptide was introduced via solid phase peptide synthesis by

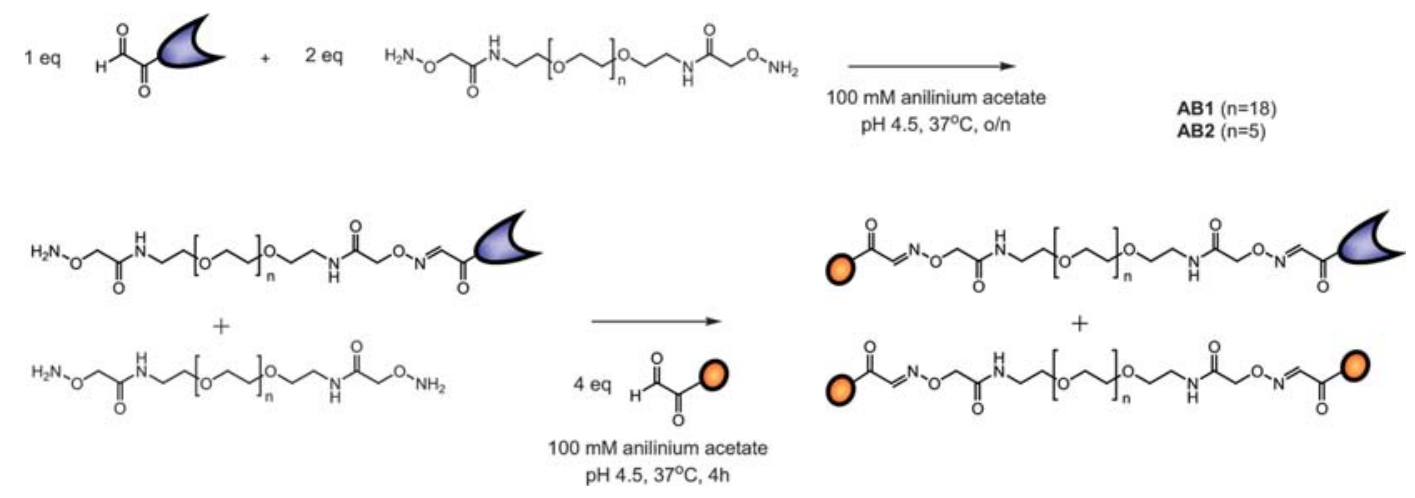

Scheme 2 Synthetic outline of the AB1 $(n=18)$ and AB2 $(n=5)$ S-peptide S-protein monomeric building blocks, formed via aniline catalyzed oxime chemistry between the oxidized serine residues on the S-peptide and S-protein and aminooxy end groups on the EG linkers. 
addition of an $\mathrm{N}$-terminal serine and subsequent $\mathrm{NaIO}_{4}$ oxidation. An aminooxy terminated oligo(ethylene glycol) linker with two different lengths was synthesized and ligated to the S-protein and S-peptide using a tandem synthetic strategy (Scheme 2). By using 2 equivalents of linker relative to S-protein and the steric hindrance resulting from the protein ligation, the mono-ligated protein product was obtained exclusively. Addition of an excess of S-peptide resulted in ligation to the remainder of the aminooxy functionalities, yielding the AB S-peptide S-protein hetero product as well as the di-S-peptide side-product. These products were purified using preparative RP-HPLC and fully characterized using LC-MS and activity assays (see ESI $\dagger$ ). The AB1 monomeric building block contains a flexible linker of 19 ethylene glycol repeats while the $\mathbf{A B 2}$ monomer contains a flexible linker of 6 ethylene glycol repeats.

As only a correctly folded and associated RNase $\mathrm{S}$ complex is enzymatically active, measurements of the enzymatic activity of the tethered RNase $\mathrm{S}$ constructs $\mathbf{A B 1}$ and $\mathbf{A B 2}$ can reveal whether the protein still contains its native structure after synthesis and that the enzyme can be used to direct self-assembly. The fluorescent 6-FAM-dArUdAdA-6-TAMRA substrate, specifically developed to quantify RNase activity, was used to monitor enzymatic activity. ${ }^{19}$ At $1-10 \mathrm{nM}$ concentrations, we obtained enzymatic activities of $\sim 60$ and $\sim 80 \%$ of that of commercially available RNase A and S for $\mathbf{A B 1}$ and $\mathbf{A B 2}$, respectively (see ESI $\dagger$ ). Since MS analysis showed no evidence that other parts of the S-protein besides the $\mathrm{N}$-terminus are oxidized during synthesis, this diminished activity could be due to substrate hindrance by the flexible EG linker. ${ }^{15}$ From the retained enzymatic activity of both $\mathbf{A B 1}$ and $\mathbf{A B 2}$ we conclude that both ends of the monomer are still able to form a native $\mathrm{RNase} \mathrm{S}$ complex and can therefore be used as a linking unit for supramolecular assemblies.

\section{Size exclusion chromatography and Q-TOF mass analysis}

Self-assembled architectures increase in weight and size with every additional monomer; therefore, size exclusion chromatography (SEC) was used to study the self-assembled structures in solution. A SEC column (Superdex 75) was coupled to a quadrupole time-of-flight (Q-TOF) mass spectrometer to enable direct and sensitive analysis of the supramolecular complexes in their self-assembled state. Different AB-monomer sample concentrations were prepared and injected after equilibration onto the SEC column and analyzed during a 30 min run at $0.1 \mathrm{ml} \mathrm{min}{ }^{-1}$ flow rate. As the buffer system $0.1 \mathrm{M}$ ammonium acetate $\mathrm{pH} 4.5$ was chosen to enable good ionization for MS analysis while strong S-peptide/S-protein complexation is preserved.

AB1 was injected after equilibration in a concentration series of $100 \mu \mathrm{M}, 1 \mathrm{mM}$ and $10 \mathrm{mM}$. Measurements at higher concentrations could not be included due to practical limitations. At the lowest concentration analyzed (Fig. 1a, dotted line) the TIC trace shows the presence of one main peak and a second smaller peak. Q-TOF MS measurements attributed the first peak to the AB1-monomer (Fig. 1b, c), whereas for the second peak no conclusive MS spectrum was obtained and it was therefore attributed to low molecular weight buffer compounds that are present in relatively large quantities compared to the protein
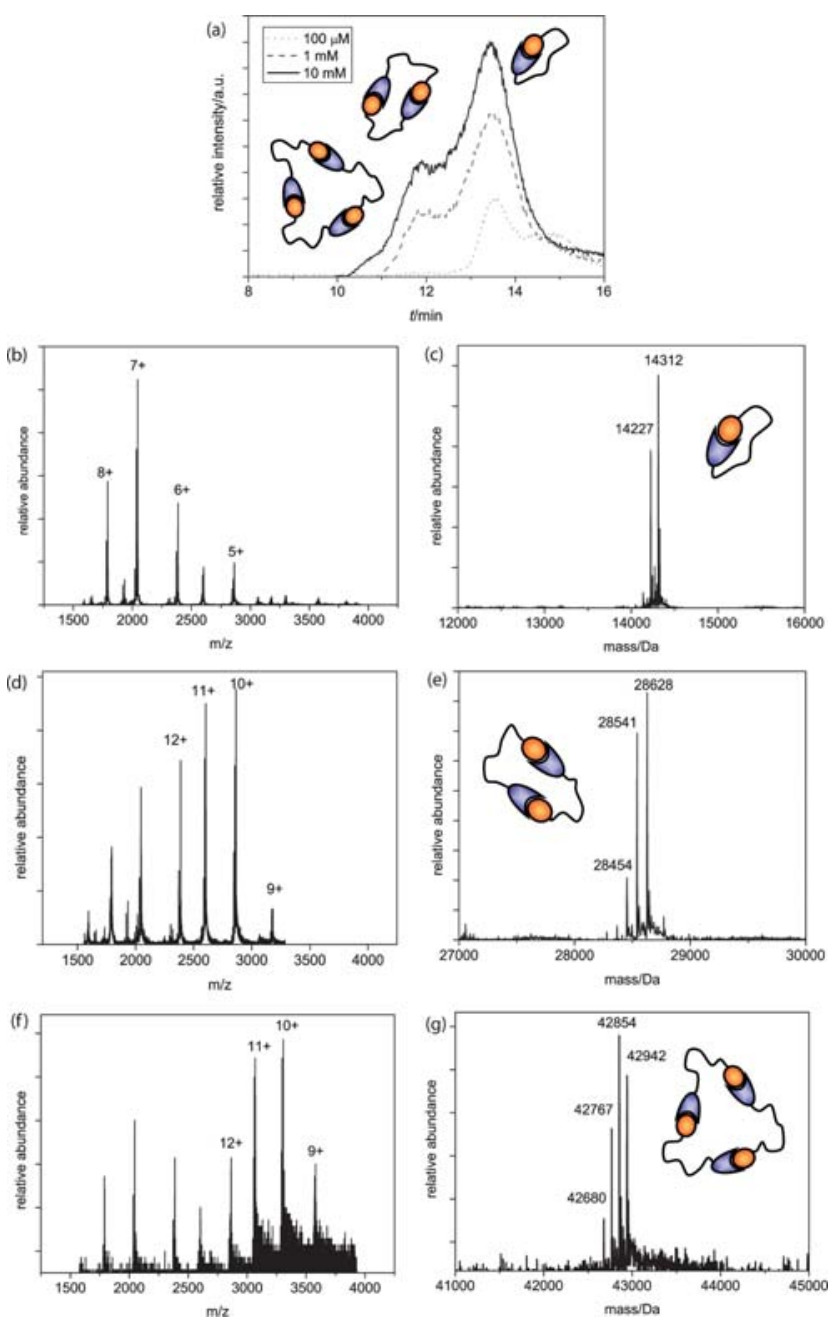

Fig. 1 (a) Q-TOF analysis chromatograms of the AB1 SEC runs, with schematic representations of ring sizes at the corresponding peaks; (b) $\mathrm{m} / \mathrm{z}$ and (c) deconvoluted spectra of the cyclic monomer $\left(\mathrm{MW}_{\text {calc }}=14314 \mathrm{Da}\right.$, $\mathrm{MW}_{\text {calc - ser }}=14227 \mathrm{Da}$ ); (d) $\mathrm{m} / \mathrm{z}$ and (e) deconvoluted spectra of the dimer $\left(\mathrm{MW}_{\text {calc }}=28628 \mathrm{Da}, \mathrm{MW}_{\text {calc }- \text { ser }}=28541 \mathrm{Da}, \mathrm{MW}_{\text {calc }-2 \text { ser }}=\right.$ $28454 \mathrm{Da})$ and (f) $\mathrm{m} / \mathrm{z}$ and (g) deconvoluted spectra of the trimer $\left(\mathrm{MW}_{\text {calc }}=\right.$ $42942 \mathrm{Da}, \quad \mathrm{MW}_{\text {calc }- \text { ser }}=42855 \mathrm{Da}, \mathrm{MW}_{\text {calc-2 ser }}=42768 \mathrm{Da}$, $\left.\mathrm{MW}_{\text {calc }-3 \mathrm{ser}}=42681 \mathrm{Da}\right)$.

monomer at this concentration. Injection of a $1 \mathrm{mM} \mathbf{A B 1}$ solution yielded not only monomeric, but also dimeric architectures (Fig. 1a, dashed line, $d+e$ ) and upon further increment of the concentration, the sample of $10 \mathrm{mM}$ showed, besides monomeric and dimeric, also trimeric species (Fig. 1a, solid line, $\mathrm{f}+\mathrm{g}$ ). DLS analysis confirmed that no larger aggregates were present (see ESI $\dagger$ ).

AB2 was injected in a concentration series of $10 \mu \mathrm{M}, 100 \mu \mathrm{M}$, $1 \mathrm{mM}$ and $10 \mathrm{mM}$ after equilibration of the mixtures. For this building block the linker is significantly shorter than for $\mathbf{A B 1}$ and therefore the equilibrium between rings and chains is expected to shift. Injection at a concentration of $10 \mu \mathrm{M}$ yielded only monomeric species (Fig. 2a, dash-dotted line, $\mathrm{b}+\mathrm{c}$ ). Injection at a higher concentration of $100 \mu \mathrm{M}$ resulted in the appearance of dimeric species (Fig. 2a, dotted line, $d+e$ ) while injection of a $1 \mathrm{mM}$ solution resulted in the formation of trimeric species 

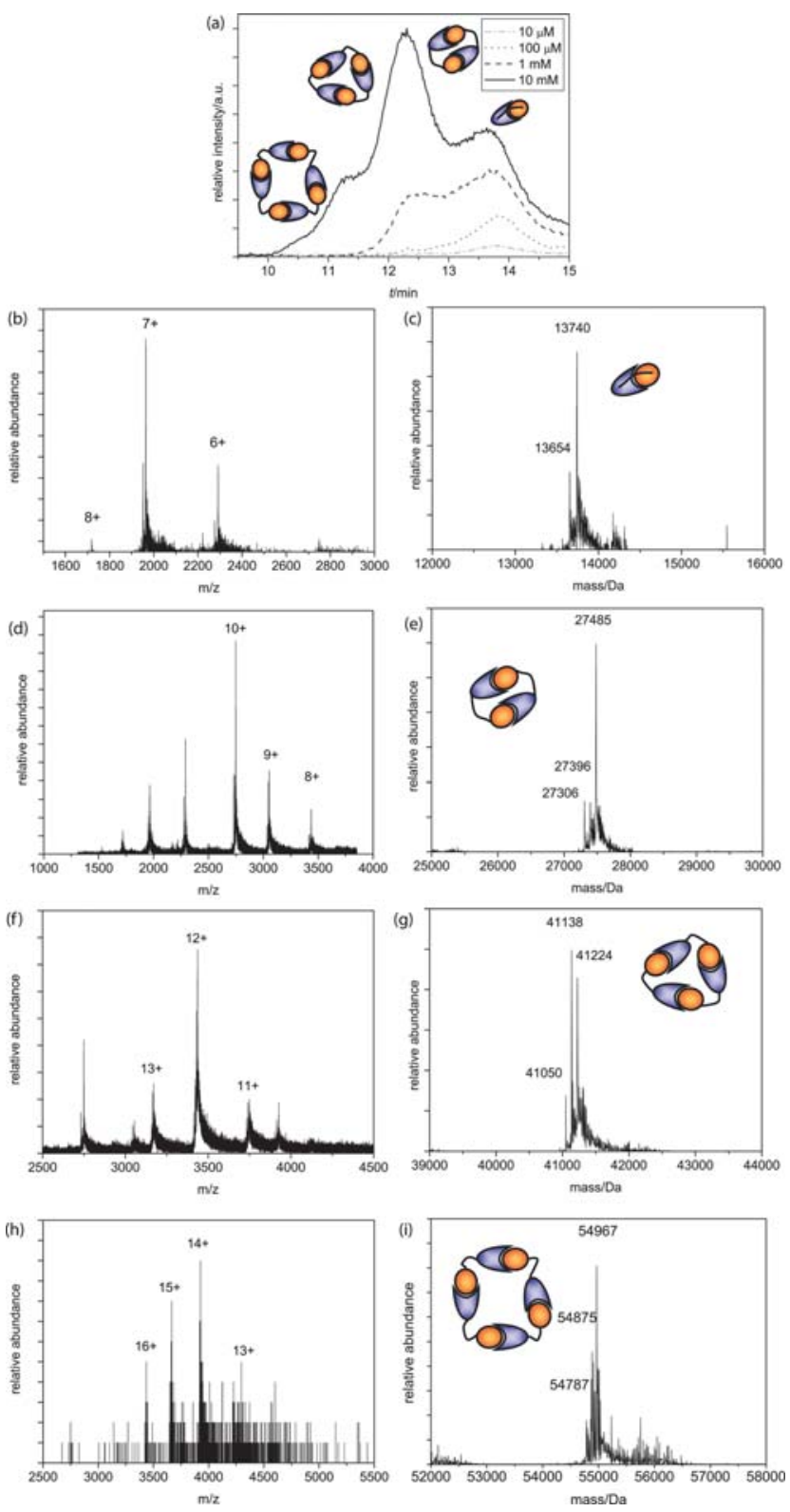

Fig. 2 (a) Q-TOF analysis chromatograms of the $10 \mathrm{mM}, 1 \mathrm{mM}$, $100 \mu \mathrm{M}$ and $10 \mu \mathrm{M}$ AB2 SEC runs, with schematic representations of ring sizes at different peaks; (b) $\mathrm{m} / \mathrm{z}$ and (c) deconvoluted spectra of the monomer $\left(\mathrm{MW}_{\text {calc }}=13740 \mathrm{Da}, \mathrm{MW}_{\text {calc }- \text { ser }}=13653 \mathrm{Da}\right) ;(\mathbf{d}) \mathrm{m} / \mathrm{z}$ and (e) deconvoluted spectra of the dimer $\left(\mathrm{MW}_{\text {calc }}=27480 \mathrm{Da}, \mathrm{MW}_{\text {calc }- \text { ser }}=\right.$ $27393 \mathrm{Da}, \mathrm{MW}_{\text {calc }-2 \text { ser }}=27306 \mathrm{Da}$ ); (f) $\mathrm{m} / \mathrm{z}$ and (g) deconvoluted spectra of the trimer $\left(\mathrm{MW}_{\text {calc }}=41220 \mathrm{Da}, \mathrm{MW}_{\text {calc }- \text { ser }}=41133 \mathrm{Da}\right.$, $\mathrm{MW}_{\text {calc }-2 \text { ser }}=41046 \mathrm{Da}$ ); (h) $\mathrm{m} / \mathrm{z}$ and (i) deconvoluted spectra of the tetramer $\left(\mathrm{MW}_{\text {calc }}=54960 \mathrm{Da}, \mathrm{MW}_{\text {calc }- \text { ser }}=54873 \mathrm{Da}, \mathrm{MW}_{\text {calc }-2 \text { ser }}=\right.$ $54786 \mathrm{Da})$.

(Fig. 2a, dashed lines, $\mathrm{f}+\mathrm{g}$ ). At a concentration of $1 \mathrm{mM} \mathbf{A B} 2$ we observe an increased amount of dimeric species compared to AB1, indicating that the short linker length in $\mathbf{A B 2}$ enforces preferential formation of these species when the overall monomer concentration is sufficient. Successive concentration increments up to a final concentration of $10 \mathrm{mM}$ showed, besides monomers, dimers and trimers, also tetrameric species (Fig. 2a, solid line, $h+$ i) and the dimer has become the predominant species. The difference in the distribution of species for the two different $\mathrm{AB}$ monomers as a function of concentration clearly demonstrates the influence of linker length on the supramolecular polymerization of the two AB monomers.

The kinetic stability of the aggregates during the course of the 15 min time interval (flow rate $=0.1 \mathrm{ml} \mathrm{min}^{-1}$ ) required for SECMS was probed by performing SEC at different flow rates. We slowed down the flow rate to $0.075 \mathrm{ml} \mathrm{min}^{-1}$, resulting in an increase in the length of time the complex spent on the column by a factor of 1.33. Integration of the peak areas of the UV chromatogram at this lower flow rate resulted in the same distribution of species observed for the higher flow rate (see ESI $\dagger$ ), indicating the kinetic stability of the aggregates is high enough not to be affected by any dilution effects that occur upon injection of the self-assembled architectures to the SEC.

\section{Calculation of the $C_{\text {eff }}$ of the monomers}

In order to corroborate the influence of ring-chain competition from our experimental data the effective concentration $\left(C_{\mathrm{eff}}\right)$ of both $\mathrm{AB}$ monomers was calculated. Theoretical methods from polymer physics can calculate the $C_{\text {eff }}$ as a function of chain length either by assuming that the linker can be modeled as a random-coil ${ }^{20-22}$ or as a worm-like chain. ${ }^{23,24}$ The theoretical concept of effective concentration is often replaced by the identical, but empirical concept of effective molarity $(E M) .{ }^{15}$ Whereas effective concentration is based on concentrations calculated from the physical properties of the chain connecting the two end groups, $E M$ denotes the ratio of the experimentally determined intra- and intermolecular equilibrium constant. For example, $\mathrm{Zhou}^{24}$ and Whitesides et al. $^{25}$ demonstrated that calculations of the $C_{\text {eff }}$ using respectively a worm-like chain model and a Gaussian chain model were in agreement with experimentally determined $E M$ values and thereby showed that this approach can provide valuable insight into complex thermodynamic phenomena such as protein-ligand binding.

We have calculated the effective concentration of the two different $\mathrm{AB}$ monomers by assuming that the end-to-end displacement vector for the ethylene glycol linker separating the two end groups has a Gaussian probability density: ${ }^{26}$

$$
p(d)=\left(\frac{3}{2 \pi<r^{2}>}\right)^{3 / 2} \exp \left(-\frac{3 d^{2}}{2<r^{2}>}\right)
$$

in which $d$ represents the distance between the two binding sites. The effective concentration is then calculated as:

$$
C_{\mathrm{eff}}(d)=p(d) / N_{\mathrm{AV}}
$$

in which $N_{\mathrm{AV}}$ is Avogadro's number. Via this approach, we neglect the possibility of excluded volume interactions between the two end groups, in this case the ligand and the protein. ${ }^{27}$

Assuming that the buffers used conform to $\theta$ conditions, the root-mean-square distance $\left\langle r^{2}\right\rangle$ can be estimated assuming a three dimensional random flight model: ${ }^{28}$

$$
<r^{2}>=C_{n} n l^{2}
$$

with $n$ the number of atoms, $l$ the bond length and $C_{n}$ the characteristic ratio. The characteristic ratio gives a measure of the 


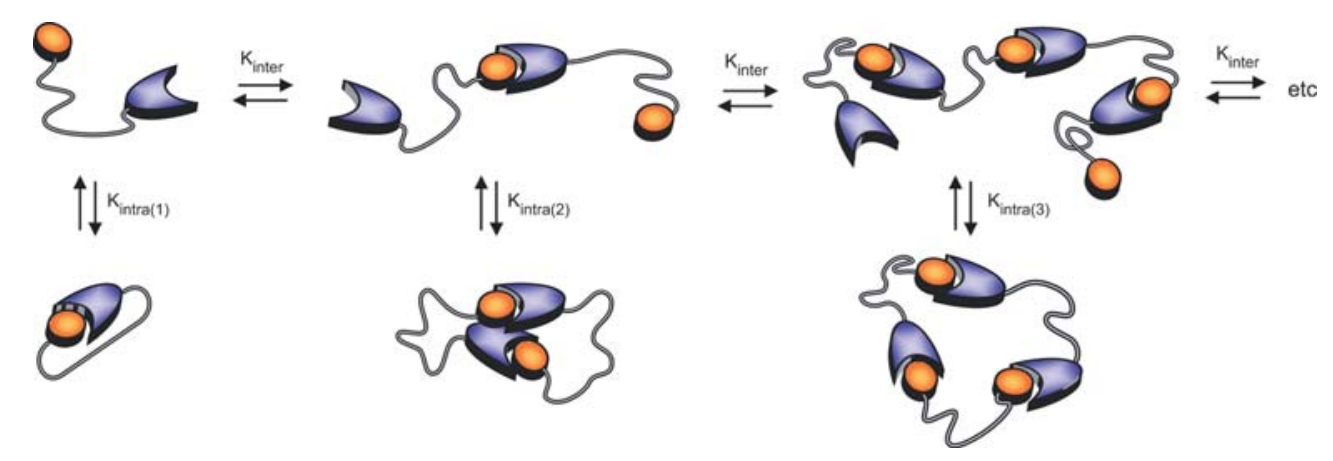

Fig. 3 Schematic representation of the ring-chain supramolecular polymerization of RNase $\mathrm{S}$ building blocks in which $K_{\text {inter }}\left(\mathrm{M}^{-1}\right)$ represents the intermolecular binding constant for bimolecular association and $K_{\operatorname{intra}(i)}$ represents the dimensionless intramolecular equilibrium constant for $i$-th ring closure.

stiffness of the chain and takes into account effects such as bond angles and rotational barriers. For long PEG chains, the characteristic ratio is found to be $4.1,{ }^{29}$ for shorter PEG chains this number decreases as given by Flory. ${ }^{30}$

Combining eqn (2) with eqn (3), relates the effective concentration to the amount of PEG repeats in a linker, for different values of the distances, $d$. The distance $d$ between the end of the S-peptide and S-protein is approximately $25 \AA^{31}$ and the number of PEG units in the linker is 19 and 6 for AB1 and AB2, respectively. Using these values and a characteristic ratio of 4.1, the calculated effective concentrations then become $8 \mathrm{mM}$ for AB1 and $0.7 \mathrm{mM}$ for AB2. ${ }^{32}$

\section{Calculation of the product distribution of a ring-chain supramolecular polymerization}

Theoretical distributions of cyclic and linear products in thermodynamically controlled (i.e. supramolecular) polymerizations were first described by Jacobson and Stockmayer (JS), ${ }^{21}$ who pointed out the existence of a critical concentration, below which the system is composed of cyclic products only and above which the concentration of cyclic species remains constant and excess monomer produces linear species only. They also related the equilibrium constant for cyclization to the cyclization probability of the chain, thereby providing a direct link between the effective molarity and the effective concentration. Ercolani et al. ${ }^{33}$ extended the treatment of JS to describe the distribution of cyclic oligomers under dilute conditions and a wide range of association constants. They pointed out that the phenomenon of a critical concentration is only manifested when the intermolecular association constant is sufficiently high $\left(>10^{5} \mathrm{M}^{-1}\right)$. Recently, Ercolani and Di Stefano ${ }^{34}$ summarized the assumptions of the JS theory: $(i)$ the thermodynamic reactivity of the end groups is independent of the chain length; (ii) all of the rings are strainless; (iii) the end-to-end distribution function of a chain in solution is Gaussian; (iv) the mean square end-to-end distance is proportional to the number of skeletal bonds (i.e. $\theta$ conditions are assumed) and ( $v)$ the cyclization probability depends on the fraction of configurations for which the ends coincide without taking into account the torsional states of the polymer chain (i.e. no angle corrections are considered). For short linkers, however, the Gaussian assumption is no longer adequate and deviations from theory and experimental data are expected (vide infra).
As most supramolecular polymerizations occur in relatively dilute solutions, the model proposed by Ercolani et al., ${ }^{33}$ is eminently suited to describe the equilibrium between cyclic and linear species in these equilibrium polymerizations. The ringchain model developed by Ercolani et al. is characterized by two distinct thermodynamic constants (Fig. 3) i.e. an intermolecular binding constant $\left(K_{\text {inter }}\right)$ and the intramolecular binding constant for $i$-th ring closure $\left(K_{\operatorname{intra}(i)}\right)$.

Under the fulfilment of conditions $(i)-(v)$, the $E M_{\mathrm{i}}$ values for $i>1$ can be conveniently written as a function of $E M_{1}$ (the effective molarity of the bifunctional $\mathrm{AB}$ monomer):

$$
E M_{i}=\frac{K_{\text {intra }(i)}}{K_{\text {inter }}}=E M_{1} i^{-\alpha}
$$

where $\alpha=5 / 2$ for self-assembling non-interacting chains. ${ }^{20}$

In such a case, the mass-balance equation takes the following form: ${ }^{33}$

$$
C_{\mathrm{t}}=\frac{1}{K_{\text {inter }}} \frac{x}{(1-x)^{2}}+E M_{1} \sum_{i=1}^{\infty} i^{-3 / 2} x^{i}
$$

in which $C_{\mathrm{t}}$ is the total concentration of monomer, $K_{\text {inter }}$ is the intermolecular equilibrium constant, $E M_{1}$ is the effective molarity of the bifunctional AB monomer, $i$ is the degree of polymerization and $x$ is the fraction of associated end groups in the chain fraction. For each $\mathrm{AB}$ monomer, we have used the value of $C_{\text {eff }}$ as calculated in the previous section for the effective molarity of the first ring closure $\left(E M_{1}\right)$. Eqn (5) can be solved for $x$ for a given monomer concentration $C_{\mathrm{t}}$. For each value of $C_{\mathrm{t}}$ the concentration of cyclic $i$-mer can then be calculated:

$$
\left[C_{\mathrm{i}}\right]=E M_{1} i^{-5 / 2} x^{i}
$$

The percentage of cyclic oligomers is then calculated as:

$$
\text { Yield of cyclic } i \text {-mer }=\frac{100 i\left[C_{i}\right]}{C_{\mathrm{t}}}
$$

Under the conditions that eqn (4) applies (vide supra), the yield of cyclic monomer is always higher than any other cyclic oligomer (Fig. S9†).

\section{Quantitative experimental analysis}

Gaussian peak deconvolution of the TIC trace of AB1 at an injection concentration of $10 \mathrm{mM}$ was performed using the 

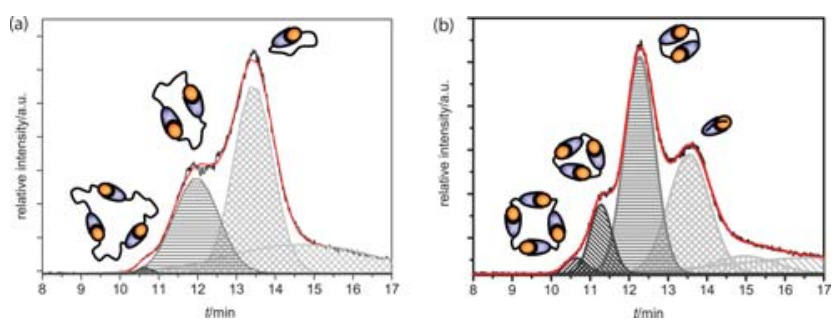

Fig. 4 (a) Gaussian peak deconvolution of the Q-TOF TIC trace of AB1 at $10 \mathrm{mM}$. Trimeric rings are represented by the dark grey peak (diagonal filling), dimeric rings by the medium grey peak (horizontal filling) and monomeric rings by the light grey peak (checker filling). With these four distinct graphs, the original curve is accurately reproduced (red line). (b) Gaussian peak fits to the Q-TOF TIC trace of AB2 at 10 mM. Tetrameric rings are represented by the black peak (diagonal filling). Trimeric rings are represented by the dark grey peak (diagonal filling), dimeric rings by the medium grey peak (horizontal filling) and monomeric rings by the light grey peak (checker filling). With these distinct graphs, the original curve is accurately reproduced (red line).

function "fit multipeaks" available in the analysis software Origin. This procedure revealed the presence of four distinct peaks at a concentration of $10 \mathrm{mM}$ (Fig. 4a). Peak areas of the chromatogram were integrated to determine the mole fraction of each oligomer. Since all cyclic structures are assembled from the same AB-monomers, ionization can be assumed equal and therefore a direct relation between TIC-trace intensity and relative concentration of the sample is justified. With the fourth peak being tailing of monomers, a distribution of $71 \pm 2.5 \%$ monomeric, $28 \pm 1 \%$ dimeric and $1 \pm 0.2 \%$ trimeric cycles was obtained. Deconvolution of the AB2 TIC-trace at $10 \mathrm{mM}$ shows a different composition, as is expected from the decreased value of $C_{\text {eff }}$ for this monomer. Six peaks were necessary to reconstruct the TIC-trace accurately, from which two peaks were necessary to account for monomer tailing and successive low molecular weight buffer compounds (Fig. 4b).

We have compared the experimentally determined product distribution with the calculated product distribution obtained using the previously discussed ring-chain competition model and a standard isodesmic polymerization model in which no cycle formation occurs. ${ }^{35}$ For both $\mathrm{AB}$ monomers an intermolecular equilibrium constant of $7 \times 10^{6} \mathrm{M}^{-1}$ was used and $E M_{1}$ values were based on the calculated $C_{\text {eff }}$ using the Gaussian chain model, thus for $\mathbf{A B 1} E M_{1}=8 \mathrm{mM}$ and for $\mathbf{A B 2} E M_{1}=0.7 \mathrm{mM}$. Comparison of the experimentally determined product distribution with the calculated product distribution determined using the ring-chain model (eqn (5)-(7)) at various total concentrations of AB1 (10, 1 and $0.1 \mathrm{mM})$ shows good correspondence (Table 1). The small deviation between theory and experiment for the AB1 monomer is most likely due to the excluded volume effects between the protein and ligand which have been neglected in the calculation of the $C_{\text {eff }}$ but have been shown to be important in other studies on reversible cyclizations. ${ }^{24,26}$ Comparison of the experimentally determined mole fractions to the calculated mole fractions obtained using an isodesmic polymerization model, in which only linear association with equilibrium constant $7 \times 10^{6}$ $\mathrm{M}^{-1}$ occurs, clearly shows that this model is unable to describe the supramolecular polymerization of monomer AB1. Hence, for this monomer, the experimental data closely obey the JacobsonStockmayer theory. As a consequence, the mole fraction of cyclic monomer is always higher than the mole fraction of any other cyclic oligomer below the critical concentration while for concentrations higher than the critical concentration, which are beyond experimental boundaries here, rapid polymerization into linear chains occurs.

Comparison of the experimentally determined product distribution of the AB2 monomer at various monomer concentrations with the Jacobson-Stockmayer theory, shows a good correspondence for the lower concentrations $(0.1 \mathrm{mM}$ and $1 \mathrm{mM})$. However, large deviations between the experimentally determined product composition and calculated values are observed at a concentration of $10 \mathrm{mM}$. Where the experimental data indicate the formation of oligomeric assemblies with the dimer as most abundant species, the ring-chain competition model, in which all cycles are assumed to be strainless, suggests the initiation of linear polymers with a $\mathrm{DP}_{n}$ of 10 . Comparison between the experimental data and values obtained using an isodesmic polymerization model show that this model cannot describe the experimental data as it predicts a number averaged degree of polymerization of 265 at this concentration. A possible explanation for the failure of the Jacobson-Stockmayer theory to describe the experimental data at higher concentrations can be found in the shorter EG linker of AB2. Discrepancy between the Jacobson-Stockmayer theory and experimental data has been observed in other studies in which short linkers have been used, for example during ring formation in covalent polymers, ${ }^{36-38}$ cyclization of short DNA fragments ${ }^{39}$ and cyclization of synthetic supramolecular polymers. ${ }^{40}$ It has been suggested that the origin of this discrepancy is due to the fact that short chains are inherently strained in their cyclic conformation and therefore do not obey Gaussian statistics, an important assumption in the derivation of eqn (4). As a result, the effective molarity of the cyclic AB2 monomer is close to, or lower than the effective molarity of the cyclic dimer and the mole fraction of cyclic dimer can surpass the mole fraction of cyclic monomer ${ }^{33}$ as is also observed experimentally. This effect is most notable at concentrations slightly above $E M_{1}$, in our case at concentrations around $10 \mathrm{mM}$.

The experimental data on the AB2 monomer elegantly show that linker composition and concentration can be used to tune the yield of a specific cyclic supramolecular biological assembly. Whereas in the AB1 monomer the linker connecting the protein and ligand is large enough for the formation of a cyclic monomer, in the AB2 monomer the formation of the cyclic monomer is hindered, resulting in high yields of the cyclic dimer at concentrations close to the critical concentration. Alternatively, the higher effective molarity of cyclic $\mathbf{A B 2}$ dimer formation compared to $\mathbf{A B 2}$ cyclic monomer formation can also be caused by additional noncovalent interactions between the two proteinligand complexes in the cyclic dimer of $\mathbf{A B 2}$.

\section{Conclusions}

The linking together of molecular fragments is a common approach in chemical biology. However, the effect of linker length, structure and rigidity on the binding affinities of the construct is seldom studied. This study describes the quantitative 
Table 1 Overview of experimental and theoretical mole percentages of the mono- and oligomeric supramolecular RNase $\mathrm{S}$ architectures. The model for ring-chain mediated supramolecular polymerization uses the calculated value of $C_{\text {eff }}$ as input for $E M_{1}$. Both the ring-chain and isodesmic models use a $K_{\mathrm{a}}$ of $7 \times 10^{6} \mathrm{M}^{-1}$

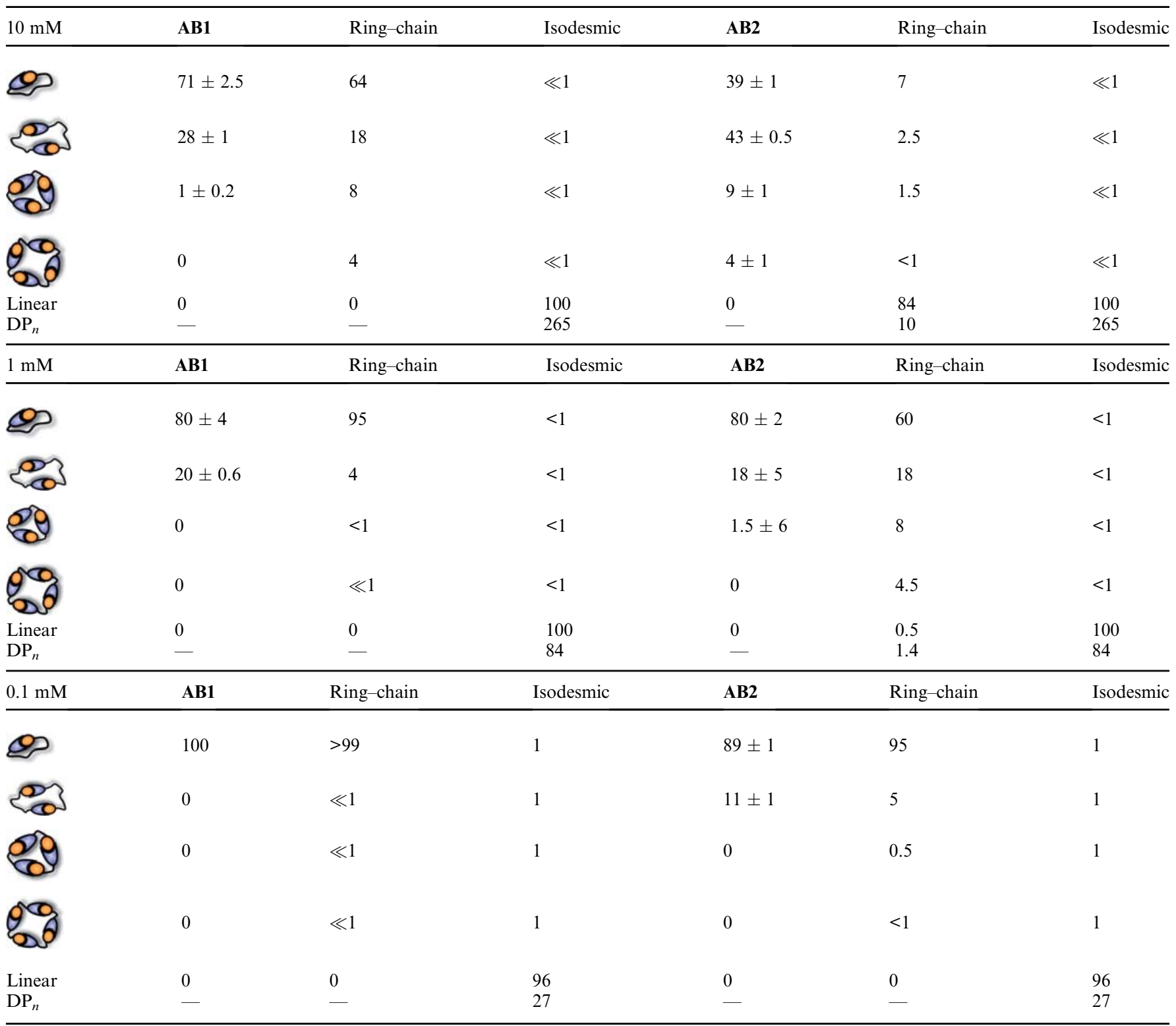

analysis of the self-assembly of peptide and protein fragments linked via a flexible oligo(ethylene glycol) linker that, upon complexation, form an active enzyme complex. Because of the tethering of the peptide and protein fragment, the system is able to reversibly polymerize into linear oligomers which are in equilibrium with their corresponding cyclic counterparts. To study the effect of linker length and the resulting changes in effective concentration, two systems were synthesized that varied in the number of ethylene oxide units in the linker, resulting in different effective concentrations, i.e. $8 \mathrm{mM}$ for $\mathbf{A B 1}$, and $0.7 \mathrm{mM}$ for AB2. Using an experimental setup where size separation was directly coupled to accurate mass spectrometry, the concentration dependent product distribution of the supramolecular polymerization could be studied in great detail.

By combining experimental data with theoretical modeling, valuable insights were obtained into the supramolecular polymerization mechanisms and design criteria for protein based supramolecular polymeric architectures. The experimentally obtained product distribution could be quantitatively described using the theory of reversible macrocyclization and shows the relation between linker length, the effective molarity of the monomer and the concentration of higher molecular weight cyclic oligomers and as such confirms that the supramolecular polymerization occurs via ring-chain competition. Consequently, the mole fraction of cyclic monomer is always higher than other cyclic oligomers below and close to the critical concentration.

The shorter linker in $\mathbf{A B 2}$ results in a decreased effective concentration for this monomer. With this decreased $C_{\text {eff }}$ the presence of various sized cyclic species as well as linearly polymerized architectures was predicted by the ring-chain competition model at the highest concentration. In sharp contrast, the 
experimental data clearly show the presence of oligomeric species instead of larger linear supramolecular polymers. The higher yield of the dimeric cycle compared to the monomeric cycle at concentrations close to the critical concentration indicates that the linker in the monomeric cycle of $\mathbf{A B 2}$ is either strained, resulting in an enthalpic contribution to the cyclization constant, or cannot be described as a random Gaussian coil. Hence, the effective molarity of cyclic $\mathbf{A B 2}$ dimer formation must be close to or even higher than the effective molarity of cyclic monomer formation, resulting in the preferred formation of the cyclic dimer at concentrations close to the critical concentration.

The described system is characterized by synthetic ease and can be analyzed in great detail. It therefore is promising in the further study of self-assembly directed by protein and peptide interactions to form active biological objects. Besides the here described $\mathrm{AB}$ homo-polymerization, the system is very suitable to study AA-BB hetero-polymerization in a comparable fashion as well as to analyze multivalency when used in combination with more branched linker structures.

When dealing with $\mathrm{AB}$ type protein monomers in which the A and $\mathrm{B}$ end groups are separated by a flexible tether, formation of linear polymers is excluded by solubility limitations and inherently only cyclic assemblies can be obtained. As implied by the ring-chain mechanism, only with an effective concentration close to 0 , where cyclization is excluded, combined with a high association constant between the $\mathrm{A}$ and $\mathrm{B}$ units that is in the order of $10^{11} \mathrm{M}^{-1}$, is linear polymerization reachable in biologically workable concentrations $\left(<10^{-3} \mathrm{M}\right)$. This is the case in several examples of supramolecular polymers found in Nature like actin filaments and microtubuli, but is hard to design for synthetic protein based $\mathrm{AB}$ building blocks. Finally, longer linear polymers can be obtained when the growth of the linear chains is coupled to growth in the lateral direction resulting in fiber like aggregates as in such a case a first order nucleated transition can occur. ${ }^{41}$ Lateral association due to the presence of a hydrophobic linker has been suggested to occur in the growth of serpin polymers in which competition between rings and chains also takes place. ${ }^{8}$

When aiming for linear polymers, cycle formation needs to be considered for all systems with flexible linkers. The ring-chain competition mechanism therefore sets out clear guidelines for the design criteria of monomeric building blocks to be used in supramolecular polymerization, either cyclic or linear.

\section{Experimental procedures}

Unless stated otherwise, all reagents and chemicals were obtained from commercial sources and used without further purification. Diamino-PEG(18) and amino-azido-PEG(5) were obtained from Polypure, 6-FAM-dArUdAdA-6-TAMRA from Integrated DNA Technologies, DIPEA and TFA from Aldrich, DCM was distilled prior to use. ESI-MS spectra were recorded on an Applied Biosystems single quadrupole electrospray ionization mass spectrometer API-150EX in positive mode. MALDI-TOF MS spectra were measured on a Perspective DE Voyager spectrometer using an $\alpha$-cyano-4-hydroxycinnamic acid matrix. Reversed phase HPLC was performed on a Shimadzu LC-8A HPLC system by using a VYDAC protein and peptide semi-prep C4 column. A gradient of water in acetonitrile, both containing $0.1 \%$ TFA was used to elute the different ligation products. Detection was performed by a Shimadzu SPD-10AV UV-detector ( $\lambda=214 \mathrm{~nm}$ ). Fluorescence spectroscopy was performed on a Varian Cary Eclipse spectrometer at $10^{\circ} \mathrm{C}$. All activity assays were performed in a $0.1 \mathrm{M}$ Tris, $0.1 \mathrm{M} \mathrm{NaCl}, \mathrm{pH}$ 8.0 buffer, with a substrate concentration of $400 \mathrm{nM}$. Size exclusion chromatography was performed on a Superdex 75 column equilibrated with $0.1 \mathrm{M}$ ammonium acetate $\mathrm{pH} 4.5$

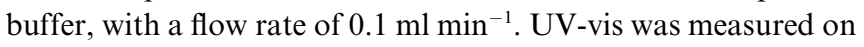
a Varian Cary UV-vis spectrometer at room temperature, and a Shimadzu LC-20AD + SPD-M20A. ESI mass analyses were performed on a Q-TOF Ultima GLOBAL mass spectrometer (Micromass, Manchester, UK).

\section{Computational procedure}

A computer script was written using Matlab R2007B. The input consists of a vector of initial concentrations, $K_{\mathrm{AB}}$ and the effective molarity of the first cyclization $\left(E M_{1}\right)$. Using a combination of bisection, secant, and inverse quadratic interpolation methods present in the Matlab script fzero, eqn (8) was solved for $x$ at each initial concentration $C$. Instead of evaluating the sum in eqn (8) from 1 to infinity it was evaluated to ring sizes up to 100 .

$$
C_{\mathrm{t}}=\frac{1}{K_{\text {inter }}} \frac{x}{(1-x)^{2}}+E M_{1} \sum_{i=1}^{\infty} i^{-3 / 2} x^{i}
$$

\section{RNase S purification}

RNase S was separated into the S-peptide and S-protein using RP-HPLC with a C4 semi-prep column. RNase S (21.63 mg) was dissolved in deionized water and eluted using a linear gradient of $0-50 \%$ acetonitrile in water over $25 \mathrm{~min}$. The S-protein was obtained in $80 \%$ yield. Mass spectrometry clearly showed the heterogeneous RNase A digestion by the protease subtilisin. Hydrolysis between amide bonds 20 and 21 as well as between 21 and 22 is observed. LC-MS: S-protein $\mathrm{MW}_{\text {calc }}=11534 \mathrm{Da}$, $\mathrm{MW}_{\text {obs }}=11533.4$ and $\mathrm{MW}_{\text {calc -ser }}=11446.9 \mathrm{Da}, \mathrm{MW}_{\mathrm{obs}}=$ 11445.8; S-peptide $\mathrm{MW}_{\text {calc }}=2095 \mathrm{Da}, \mathrm{MW}_{\mathrm{obs}}=2094.8$ and $\mathrm{MW}_{\text {calc }}+{ }_{\text {ser }}=2166 \mathrm{Da}, \mathrm{MW}_{\mathrm{obs}}=2165.7$

\section{Diaminooxy linker}

PEG(18)-diamine (100 mg) was reacted with NHS-activated tBoc-protected aminooxy $(69 \mathrm{mg})$ and DIPEA $(120 \mu \mathrm{L})$ in dry $\mathrm{CH}_{2} \mathrm{Cl}_{2}(2 \mathrm{~mL})$ overnight. The solution was stirred for 30 minutes with diethyl ether $(5 \mathrm{~mL})$ and, after removal of the solvent, for another 15 minutes with $3 \mathrm{~mL}$ diethyl ether. After solvent evaporation, NHS was removed by application of the product on a weak basic ion exchanger (ira 95, $6 \times 1 \mathrm{~cm}$ ) eluted with $\mathrm{MeOH}$. Deprotection of the $\mathrm{tBoc}$ groups was achieved upon dilution in DCM/TFA $(3 / 3 \mathrm{~mL})$ at $0{ }^{\circ} \mathrm{C}$ for 2 hours. Cold solvent evaporation and co-evaporation with toluene removed the residual TFA. After water/ether extractions, the product was lyophilized.

Azido-PEG(5)-amine was reduced with $\mathrm{Pd} / \mathrm{C}$ and $\mathrm{H}_{2}$ gas to obtain the diamine prior to use. PEG(5)-diamine (195 mg) was reacted with NHS-activated tBoc-protected aminooxy (381 mg) and DIPEA $(500 \mu \mathrm{L})$ in dry $\mathrm{CH}_{2} \mathrm{Cl}_{2}(4 \mathrm{~mL})$ overnight. After 
solvent evaporation, the product was dissolved in $40 \mathrm{~mL} \mathrm{CHCl}_{3}$ and washed $2 \times$ with $40 \mathrm{~mL} \mathrm{NaHCO}_{3}$ and once with $40 \mathrm{~mL}$ brine. After drying with $\mathrm{MgSO}_{4}$ and filtration, the product was purified on a silica column with DCM/MeOH (20/3 mL). Deprotection of the $\mathrm{tBoc}$ groups was achieved upon dilution in TFA/ $\mathrm{H}_{2} \mathrm{O}(5 / 0.25$ $\mathrm{mL}$ ) at $0{ }^{\circ} \mathrm{C}$ for 1 hour. After cold solvent evaporation the product was dissolved in $20 \mathrm{~mL}$ water and washed with $2 \times 10$ $\mathrm{mL}$ diethyl ether. After removal of the diethyl ether the product was lyophilized.

${ }^{1} \mathrm{H}$ NMR $\left(\mathrm{CDCl}_{3}-\mathrm{d}_{1}, 400 \mathrm{MHz}\right)$ : tBoc-protected PEG18 linker $\delta=8.2\left(\mathrm{~s}, 2 \mathrm{H}, \mathrm{CH}_{2}-\mathrm{N} H-\mathrm{C}=\mathrm{O}\right), \delta=7.8(\mathrm{bs}, 2 \mathrm{H}, \mathrm{O}-\mathrm{N} H-\mathrm{C}=\mathrm{O})$, $\delta=4.6\left(\mathrm{~s}, 4 \mathrm{H}, \mathrm{O}-\mathrm{CH}_{2}-\mathrm{C}=\mathrm{O}\right), \delta=3.6-3.7\left(80 \mathrm{H}, \mathrm{O}-\mathrm{CH}_{2}-\mathrm{CH}_{2}-\right.$ $\mathrm{O}), \delta=1.5\left(18 \mathrm{H}, \mathrm{C}-\left(\mathrm{CH}_{3}\right)_{3}\right) ;{ }^{1} \mathrm{H} \mathrm{NMR}\left(\mathrm{CDCl}_{3}-\mathrm{d}_{1}, 400 \mathrm{MHz}\right)$ : unprotected PEG18 linker $\delta=8.1$ (bs, $\left.2 \mathrm{H}, \mathrm{CH}_{2}-\mathrm{NH}-\mathrm{C}=\mathrm{O}\right), \delta=$ 4.7 (bs, $\left.4 \mathrm{H}, \mathrm{O}-\mathrm{CH}_{2}-\mathrm{C}=\mathrm{O}\right), \delta=3.6-3.8\left(80 \mathrm{H}, \mathrm{O}-\mathrm{CH}_{2}-\mathrm{CH}_{2}-\mathrm{O}\right)$; ${ }^{13} \mathrm{C}$ NMR $\left(\mathrm{CDCl}_{3}-\mathrm{d}_{1}, 400 \mathrm{MHz}\right)$ : tBoc-protected PEG18 linker $\delta=169.01,157.39,82.42,75.85,70.57,69.60,38.92,28.20 ;{ }^{13} \mathrm{C}$ NMR $\left(\mathrm{CDCl}_{3}-\mathrm{d}_{1}, 400 \mathrm{MHz}\right)$ : unprotected PEG18 linker $\delta=$ 168.70, 71.64, 69.49, 69.29, 68.52, 38.62; MALDI-TOF MS protected PEG18 linker $\mathrm{MW}_{\text {calc }}=1243.43 \mathrm{Da}, \mathrm{MW}_{\mathrm{obs}}=$ 1265.70 Da $\left(\mathrm{Na}^{+}\right)$; MALDI-TOF MS unprotected PEG18 linker $\mathrm{MW}_{\text {calc }}=1043.20 \mathrm{Da}, \mathrm{MW}_{\mathrm{obs}}=1043.62 \mathrm{Da}$.

${ }^{1} \mathrm{H}$ NMR $\left(\mathrm{CDCl}_{3}-\mathrm{d}_{1}, 400 \mathrm{MHz}\right)$ : tBoc-protected PEG5 linker $\delta=8.2\left(\mathrm{~s}, 2 \mathrm{H}, \mathrm{CH}_{2}-\mathrm{N} H-\mathrm{C}=\mathrm{O}\right), \delta=7.8(\mathrm{bs}, 2 \mathrm{H}, \mathrm{O}-\mathrm{N} H-\mathrm{C}=\mathrm{O})$, $\delta=4.4\left(\mathrm{~s}, 4 \mathrm{H}, \mathrm{O}-\mathrm{CH}_{2}-\mathrm{C}=\mathrm{O}\right), \delta=3.6-3.7\left(\mathrm{~m}, 24 \mathrm{H}, \mathrm{O}-\mathrm{CH}_{2}-\right.$ $\left.\mathrm{CH}_{2}-\mathrm{O}\right), \delta=3.5\left(\mathrm{q}, 4 \mathrm{H}, \mathrm{NH}-\mathrm{CH}_{2}-\mathrm{CH}_{2}-\mathrm{O}\right), \delta=1.5(18 \mathrm{H}, \mathrm{C}-$ $\left.\left(\mathrm{CH}_{3}\right)_{3}\right) ;{ }^{1} \mathrm{H} \mathrm{NMR}\left(\mathrm{CDCl}_{3}-\mathrm{d}_{1}, 400 \mathrm{MHz}\right)$ : unprotected PEG5 linker $\delta=8.0\left(\mathrm{bs}, 2 \mathrm{H}, \mathrm{CH}_{2}-\mathrm{NH}-\mathrm{C}=\mathrm{O}\right), \delta=4.5\left(4 \mathrm{H}, \mathrm{O}-\mathrm{CH}_{2}-\right.$ $\mathrm{C}=\mathrm{O}), \delta=3.6-3.7\left(24 \mathrm{H}, \mathrm{O}-\mathrm{CH}_{2}-\mathrm{CH}_{2}-\mathrm{O}\right), \delta=3.5(\mathrm{~m}, 4 \mathrm{H}, \mathrm{NH}-$ $\left.\mathrm{CH}_{2}-\mathrm{CH}_{2}-\mathrm{O}\right), \delta=1.9\left(4 \mathrm{H}, \mathrm{O}-\mathrm{N} H_{2}\right) ;{ }^{13} \mathrm{C} \mathrm{NMR}\left(\mathrm{CDCl}_{3}-\mathrm{d}_{1}, 400\right.$ $\mathrm{MHz}$ ): tBoc-protected PEG5 linker $\delta=169.06,157.37$, 82.42, 75.79, 70.53, 69.56, 38.93, 28.20.

\section{Ser-S-peptide}

The ser-S-peptide was a kind gift from Edith Lempens. ${ }^{42}$

\section{N-terminal serine oxidation}

1 equiv. of S-protein or ser-S-peptide was reacted with 1.2 equiv. of $\mathrm{NaIO}_{4}$ during $5 \mathrm{~min}$ in $\mathrm{pH} 7.4$ PBS buffer at a concentration of $\sim 1 \mathrm{mg}$ protein $\mathrm{ml}^{-1}$ at $4{ }^{\circ} \mathrm{C}$. Direct RP-HPLC purification of the reaction mixture was carried out with a semi-prep $\mathrm{C} 4$ column using a linear gradient of $10-35 \%$ acetonitrile in water over 25 min. The oxidized S-protein was obtained in $70 \%$ yield. ESI-QTOF S-protein $\mathrm{MW}_{\text {calc }}=11503 \mathrm{Da}, \mathrm{MW}_{\mathrm{obs}}+\mathrm{OH}=11519 \mathrm{Da}$, $\mathrm{MW}_{\text {obs }}=11501 \mathrm{Da}, \mathrm{MW}_{\text {calc-ser }}=11416 \mathrm{Da}, \mathrm{MW}_{\text {obs-ser }+\mathrm{OH}}=$ $11433 \mathrm{Da}, \mathrm{MW}_{\text {obs-ser }}=11414 \mathrm{Da}$; LC-MS S-peptide $\mathrm{MW}_{\text {calc }}=$ $1805 \mathrm{Da}, \mathrm{MW}_{\mathrm{obs}}+\mathrm{OH}=1821 \mathrm{Da}, \mathrm{MW}_{\mathrm{obs}}=1805 \mathrm{Da}$.

\section{AB-monomer synthesis}

1 equiv. of oxidized S-protein was reacted with 2 equiv. of aminooxy-linker in $0.1 \mathrm{M}$ anilinium acetate $\mathrm{pH} 4.5$ buffer at $37^{\circ} \mathrm{C}$ overnight. 4 equiv. of oxidated ser-S-peptide was added to the reaction mixture and ligated in $4 \mathrm{~h}$ at $37{ }^{\circ} \mathrm{C}$ to yield the $\mathrm{AB}-$ monomer as well as the AA-peptide-monomer. Separation and purification of the products was achieved with RP-HPLC using a Vydac C4 semi-prep column with a linear gradient of $10-50 \%$ over $40 \mathrm{~min}$. The AB-monomer was obtained in $40 \%$ yield relative to the S-protein. ESI-Q-TOF AB1 $\mathrm{MW}_{\text {calc }}=14314 \mathrm{Da}$, $\mathrm{MW}_{\text {obs }}=14313.9 \mathrm{Da}, \mathrm{MW}_{\text {calc-ser }}=14227 \mathrm{Da}, \mathrm{MW}_{\text {obs-ser }}=$ 14227.1 Da. ESI-Q-TOF AB2 $\mathrm{MW}_{\text {calc }}=13740 \mathrm{Da}, \mathrm{MW}_{\mathrm{obs}}=$ $13740 \mathrm{Da}, \mathrm{MW}_{\text {calc-ser }}=13653 \mathrm{Da}, \mathrm{MW}_{\text {obs-ser }}=13654 \mathrm{Da}$.

\section{Activity assay}

RNase A was dissolved in assay buffer $(0.1 \mathrm{M}$ Tris, $0.1 \mathrm{M} \mathrm{NaCl}$, $\mathrm{pH} 8.0)$ to a $40 \mu \mathrm{M}$ stock. Upon addition of substrate $(400 \mathrm{nM})$, fluorescence emission was monitored in time at $515 \mathrm{~nm}$ with excitation at $490 \mathrm{~nm}$. The initial reaction rate $V_{0}$ was calculated from a linear fit of the emission intensity in time over the first 30 s. A concentration range of RNase A was prepared and measured to obtain a calibration curve (1-10 nM; dilutions were freshly made before each measurement).

\section{Size exclusion chromatography and ESI-QTOF mass spectrometry}

Size exclusion chromatography was performed using a Superdex 75 column (GE Biosciences) equilibrated with $0.1 \mathrm{M}$ ammonium acetate $\mathrm{pH}$ 4.5. The AB-monomer was dissolved in the same buffer to concentrations of $10 \mathrm{mM}, 1 \mathrm{mM}$ and $100 \mu \mathrm{M}$ and incubated for one hour. Samples were injected onto the equili-

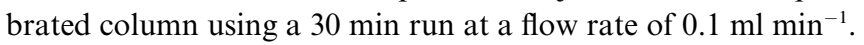
ESI-QTOF mass spectrometry was performed on a Micromass QTOF Ultima Global mass spectrometer in positive mode. The flow outlet of the Superdex 75 size exclusion column was connected to the inlet of the mass spectrometer. Micromass MaxEnt 1 software was used for deconvolution.

Flow speed analysis was performed on a Superdex 75 column coupled to UV-vis (Shimadzu LC-20AD liquid chromatography, Shimadzu SPD-M20A prominence diode detector, $230 \mathrm{~nm}$ ). Flow speed was varied from $0.1 \mathrm{ml} \mathrm{min}^{-1}$ to $0.075 \mathrm{ml} \mathrm{min}^{-1}$. Manual injections were performed with $4 \mu \mathrm{L}$ samples in $0.1 \mathrm{M}$ ammonium acetate, $\mathrm{pH} 4.5$.

\section{Acknowledgements}

The authors would like to thank Bas de Waal for synthetic help, Edith Lempens for providing the S-peptide, Holger Grüll and Sander Langereis for assistance with DLS, and the Council for Chemical Sciences of the Netherlands Organization of Scientific Research (CW-NWO) for financial support.

\section{Notes and references}

1 Supramolecular polymers general: (a) L. Brunsveld, B. J. B. Folmer, E. W. Meijer and R. P. Sijbesma, Chem. Rev., 2001, 101, 4071; (b) P. S. Corbin and S. C. Zimmerman, in Supramolecular Polymers, ed. A. Ciferri, Marcel Dekker, New York, 2000, p. 147; (c) A. Ciferri, J. Macromol. Sci., Polym. Rev., 2003, 43, 271; (d) J.M. Lehn, Polym. Int., 2002, 51, 825; (e) A. J. Wilson, Soft Matter, 2007, 3, 409; $(f)$ L. Bouteiller, Adv. Polym. Sci., 2007, 207, 79; M. J. Serpe and S. L. Craig, Langmuir, 2007, 23, 1626; $(g)$ A. Harada, A. Hashidzume and Y. Takashima, Adv. Polym. Sci., 2006, 201, 1; (h) F. Huang, D. S. Nagvekar, X. Zhou and H. W. Gibson, Macromolecules, 2007, 40, 356; (i) C. A. Hunter and S. Tomas, J. Am. Chem. Soc., 2006, 128, 8975; (j) H. Kitagishi, K. Oohora, H. Yamaguchi, H. Sato, T. Matsuo, A. Harada and T. Hayashi, J. Am. Chem. Soc., 2007, 129, 10326; (k) V. H. Soto Tellini, A. Jover, J. C. Garcia, L. Galantini, F. Meijide and J. V. Tato, J. Am. Chem. Soc., 2006, 128, 5728; (l) R. K. Castellano, R. Clark, S. L. Craig, C. Nuckolls and J. Rebek 
Jr., Proc. Natl. Acad. Sci. U. S. A., 2000, 97, 12418; (m) V. Berl, M. Schmutz, M. J. Krische, R. G. Khoury and J. M. Lehn, Chem.Eur. J., 2002, 8, 1227; (n) W. H. Binder, C. Bernstoff, L. Kluger, L. Petraru and M. J. Kunz, Adv. Mater., 2005, 17, 2824; (o) T. F. A. de Greef and E. W. Meijer, Nature, 2008, 453, 171; $(p)$ T. F. A. de Greef, M. M. J. Smulders, M. Wolffs, A. P. H. J. Schenning, R. P. Sijbesma and E. W. Meijer, Chem. Rev., 2009, 109, 5687.

2 (a) R. P. Sijbesma, F. H. Beijer, L. Brunsveld, B. J. B. Folmer, J. H. K. K. Hirschberg, R. F. M. Lange, J. K. L. Lowe and E. W. Meijer, Science, 1997, 278, 1601; (b) P. Y. W. Dankers, E. N. M. van Leeuwen, G. M. L. van Gemert, A. J. H. Spiering, M. C. Harmsen, L. A. Brouwer, H. M. Janssen, A. W. Bosman, M. J. A. van Luyn and E. W. Meijer, Biomaterials, 2006, 27(32), 5490; (c) Patricia Y. W. Dankers, Martin C. Harmsen, Linda A. Brouwer, Marja J. A. Van Luyn and E. W. Meijer, Nat. Mater., 2005, 4(7), 568.

3 Isodesmic supramolecular polymerizations: (a) S. Lahiri, J. L. Thompson and J. S. Moore, J. Am. Chem. Soc., 2000, 122, 11315; (b) D. Zhao and J. S. Moore, J. Org. Chem., 2002, 67, 3548; (c) M. Kastler; W. Pisula; D. Wasserfallen; T. Pakula.; K. Müllen; (d) F. Würthner, C. Thalacker, S. Diele and C. Tschierske, Chem.Eur. J., 2001, 7, 2245.

4 Cooperative supramolecular polymerizations: (a) M. M. J. Smulders, A. P. H. J. Schenning and E. W. Meijer, J. Am. Chem. Soc., 2008, 130, 606; (b) P. Jonkheijm, P. P. A. M. van der Schoot, A. P. H. J. Schenning and E. W. Meijer, Science, 2006, 313, 80; (c) V. Simic, L. Bouteiller and M. Jalabert, J. Am. Chem. Soc., 2003, 125, 13148; (d) F. Lortie, S. Boileau and L. Bouteiller, Chem.-Eur. J., 2003, 9, 3008; (e) A. Arnaud, J. Belleney, F. Boué, L. Bouteiller, G. Carrot and V. Wintgens, Angew. Chem., Int. Ed., 2004, 43, 1718; (f) P. P. A. M. van der Schoot, M. A. J. Michels, L. Brunsveld, R. P. Sijbesma and A. Ramzi, Langmuir, 2000, 16, 10076.

5 Ring-chain mediated supramolecular polymerizations: (a) A. T. ten Cate, H. Kooijman, A. L. Spek, R. P. Sijbesma and E. W. Meijer, J. Am. Chem. Soc., 2004, 126, 3801; (b) T. F. A. de Greef, G. Ercolani, G. B. W. L. Ligthart, E. W. Meijer and R. P. Sijbesma, J. Am. Chem. Soc., 2008, 130, 13755; (c) H. W. Gibson, N. Yamaguchi and J. W. Jones, J. Am. Chem. Soc., 2003, 125, 3522; (d) K. Ohga, H. Takahashi, Y. Kawaguchi, H. Yamaguchi and A. Harada, Macromolecules, 2005, 38, 5897; (e) C. Schmuck, T. Rehm, L. Geiger and M. Schäfer, J. Org. Chem., 2007, 72, 6162; $(f)$ V. G. H. Lafitte, A. E. Aliev, P. N. Horton, M. B. Hursthouse and H. C. Hailes, Chem. Commun., 2006, 2173; (g) S. J. Cantrill, G. J. Youn and J. F. Stoddart, J. Org. Chem., 2001, 66, 6857; (h) J. Xu, E. A. Fogleman and S. L. Craig, Macromolecules, 2004, 37, 1863; (i) F. Wang, C. Han, C. He, Q. Zhou, J. Zhang, C. Wang, N. Li and F. Huang, J. Am. Chem. Soc., 2008, 130, 11254.

6 F. Oosawa and M. Kasai, J. Mol. Biol., 1962, 4, 10.

7 G. Rivas, A. Lopez, J. Mingorance, M. J. Ferrandiz, S. Zorrilla, A. P. Minton, M. Vicente and J. M. Andreu, J. Biol. Chem., 2000, 275, 11740-11749.

8 M. Yamasaki, W. Li, D. J. D. Johnson and J. A. Huntington, Nature, 2008, 455, 1255-1259.

9 (a) H. Yamaguchi and A. Harada, Biomacromolecules, 2002, 3, $1163-$ 1169; (b) H. Yamaguchi and A. Harada, Top. Curr. Chem., 2003, 228, 237-258.

10 H. Kitagishi, Y. Kakikura, H. Yamaguchi, K. Oohora, A. Harada and T. Hayashi, Angew. Chem., Int. Ed., 2009, 48(7), 1271-1274.

11 (a) J. C. T. Carlson, S. S. Jena, M. Flenikken, T. Chou, R. A. Siegel and C. R. Wagner, J. Am.Chem. Soc., 2006, 128, 7630-7638; (b) T. F. Chou, C. So, J. T. C. Carlson, B. R. White, M. Sarikaya and C. Wagner, ACS Nano, 2008, 2, 2519-2525.

12 W. Kuhn, Kolloid Z., 1934, 68, 2.
13 (a) R. T. Raines, Chem. Rev., 1998, 98, 1045-1065; (b) P. R. Connelly, R. Varadarajan, J. M. Sturtevant and F. M. Richards, Biochemistry, 1990, 29, 6108-6114; (c) confirmed by ITC measurements (not published).

14 E. H. M. Lempens, I. van Baal, J. L. J. van Dongen, T. M. Hackeng, M. Merkx and E. W. Meijer, Chem.-Eur. J., 2009, 15, 8760-8767.

15 S. Kubetzko, C. A. Sarkar and A. Pluckthun, Mol. Pharmacol., 2005, 68, 1439

16 (a) A. Dirksen, S. Dirksen, T. M. Hackeng and P. E. Dawson, J. Am. Chem. Soc., 2006, 128, 15602; (b) A. Dirksen, T. M. Hackeng and P. E. Dawson, Angew. Chem., Int. Ed., 2006, 45, 7581.

17 K. F. Geoghegan and J. G. Stroh, Bioconjugate Chem., 1992, 3, 138-146.

18 (a) M. S. Doscher and C. H. W. Hirs, Biochemistry, 1967, 6, 304-312; (b) T. J. Mendez, J. V. Johnson and D. E. Richardson, Anal. Biochem., 2000, 279, 114-118.

19 (a) B. R. Kelemen, T. A. Klink, M. A. Behlke, S. R. Eubanks, P. A. Leland and R. T. Raines, Nucleic Acids Res., 1999, 27, 36963701; (b) C. Park, B. R. Kelemen, T. A. Klink, R. Y. Sweeney, M. A. Behlke, S. R. Eubanks and R. T. Raines, Methods Enzymol., 2001, 341, 81-94.

20 L. Mandolini, Adv. Phys. Org. Chem., 1987, 22, 1-111.

21 H. Jacobson and W. H. Stockmayer, J. Chem. Phys., 1950, 18, 16001606.

22 (a) A. Mulder, T. Auletta, A. Sartori, S. Del Ciotto, A. Casnati, R. Ungaro, J. Huskens and D. N. Reinhoudt, J. Am. Chem. Soc., 2004, 126, 6627-6636; (b) R. H. Kramer and J. W. Karpen, Nature, 1998, 395, 710-713.

23 T. H. Evers, E. M. W. M. van Dongen, A. C. Faesen, E. W. Meijer and M. Merkx, Biochemistry, 2006, 45(44), 13183-13192.

24 (a) H. X. Zhou, J. Phys. Chem. B, 2001, 105(29), 6763-6766; (b) H. X. Zhou, J. Am. Chem. Soc., 2001, 123, 6730-6731; (c) H. X. Zhou, J. Mol. Biol., 2003, 329, 1-8.

25 V. M. Krishnamurthy, V. Semetey, P. J. Bracher, N. Shen and G. M. Whitesides, J. Am. Chem. Soc., 2007, 129(5), 1312-1320.

26 H. X. Zhou, Biochemistry, 2004, 43, 2141.

27 J. M. Gargano, T. Ngo, J. Y. Kim, D. W. K. Acheson and W. J. Lees, J. Am. Chem. Soc., 2001, 123, 12909-12910.

28 P. J. Flory, Principles of Polymer Chemistry, Cornell University Press, Ithaca, NY, 1953.

29 S. P. Powers, I. Foo, D. Pinon, U. G. Klueppelberg, J. F. Hedstrom and L. J. Miller, Biochemistry, 1991, 30, 676-682.

30 P. J. Flory, Statistical Mechanics of Chain Molecules, WileyInterscience, New York, 1969.

31 Determined via PyMol, PDB 1FS3.

32 For long PEG chains the characteristic ratio is found to be 4.1 , for shorter PEG chains this number decreases as given by Flory, to $\sim 3.9$ for a 6-repeat EG spacer. However, contributions of the flexible ends of the S-protein and S-peptide justify the use of 4.1 for our AB2 system.

33 G. Ercolani, L. Mandolini, P. Mencarelli and S. Roelens, J. Am. Chem. Soc., 1993, 115, 3901-3908.

34 G. Ercolani and S. Di Stefano, J. Phys. Chem. B, 2008, 112, 46624665.

35 R. B. Martin, Chem. Rev., 1996, 96, 3043-3064.

36 J. A. Semlyen, Adv. Polym. Sci., 1976, 21, 41.

37 H. Morawetz and N. Goodman, Macromolecules, 1970, 3, 699.

38 Y. Yamashita, J. Mayumi, Y. Kawakami and K. Ito, Macromolecules, 1980, 13, 1075.

39 D. Shore and R. L. Baldwin, J. Mol. Biol., 1983, 170, 957.

40 S. Abed, S. Boileau and L. Bouteiller, Macromolecules, 2000, 33, 8479-8487.

41 B. A. H. Huisman, P. G. Bolhuis and A. Fasolino, Phys. Rev. Lett., 2008, 100, 188301.

42 E. H. M. Lempens, B. A. Helms, M. Merkx and E. W. Meijer, ChemBioChem, 2009, 10, 658-662. 